\title{
日本産ウシノシタ魚類の成長について
}

\author{
落 合明 \\ （京都大学農学部水鷹学教室）。
On the Growth Pattern of the Soleoid Fishes Taken Mainly from Southern Part of Japan

\begin{abstract}
Akira OCHIAI
The growth differentiation found among 19 Japanese soles obtained from southern part of Japan is quantitatively viewed with several biological aspects.

At the age of 3 years, the body reaches $100 \mathrm{~mm}$ or even becomes longer in the fishes belonging to the subfamily Synapturinae, but in those of the other subfamilies of Soleidae (Soleinae and Achirinae) it is usually shorter. In the family Cynoglossidae, the members of the subfamily of Cynoglossinae attain on the whole more than $100 \mathrm{~mm}$ in the body length, whereas the fishes of the Symphirinae never reach $100 \mathrm{~mm}$.

According to extremity body length calculated by the difference diagram, each of the tropical, subtropical and temperate forms is clearly divided into 3 groups. But the 1ropical form is always more or less longer than the others (Fig. 3). It also seems probable that in the same genus the species originated in the tropical ocean have a longer body than the endemic ones of Japan and China (i.e. : Zebrias zebra-Z. japonicus, Aseraggodes kaianus-A. kobensis, Symphurus strictus-S. orientalis).

There is a tendency in this group that the higher counts anal soft rays the fish has, the larger the body becomes.
\end{abstract}

氷座資源の調查が広く行われるようになつてから，多くの魚類の成長が次第に明らかとなつてきた。成長 率は年令組成・生残率等と䦩連しているばかりでなく，㮔の分化を解眀するうえにもしばしば有力な手がか りとなることがある。一つの属まなば科内の種類の成舆状態を調查すると，多くの場合二つないしてれ上上 の群分かれる。そしてその場合近似種の矮小型と巨大型との間炕は，形態上の分化が成長の分化上関尰し て起つたと考えられる場合がしばしばある。

筆者はここで日本圱りシノシタ類 19 種の成長状態が，分類学上の地位，地理的分布改び形態上の差翼な どとどのよ5な関係にあるかを究明したい。ウシノシタ魚類は，分類学上ササウシノシタ科とウジタシタ科

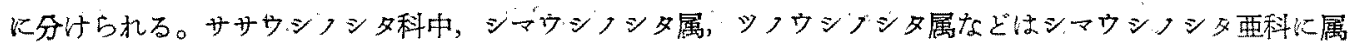
する。ウシフシタ科はウシノシダ业科とアズマがレイ亜科とに分けられる。ここでササウシフシタ科とシマ ウシフシタ科とを一括したのは，これらが分類学上近縁であるばかりでなく，何れも暖流系のるので同じ様 な生態・習性を持つからである。

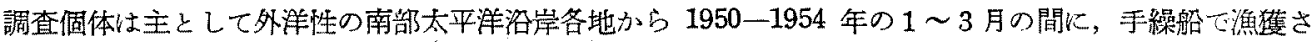

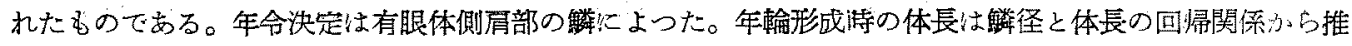
定した。また，各種の分右をあらか才指数として，これらの分布の北限と南限の緯度の平均倬を用いた。れ

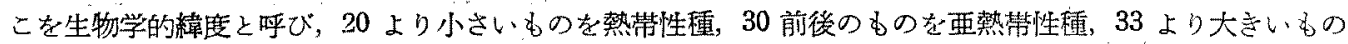

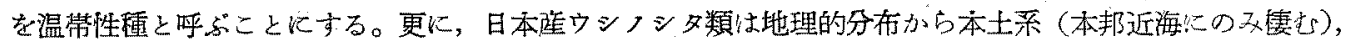

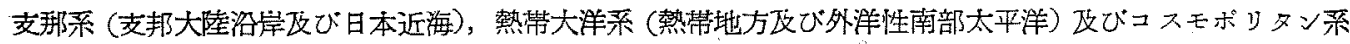

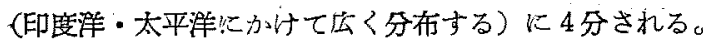

本研究をすすめるにおたつて，ご指導を賜わり本稿を校閲して下さつた松原喜代松教授に厚くお礼を申し 上げる。なお，この研究は文部省科学研究費の一部によつて行われたるのである。 


\section{研 究 結 果}

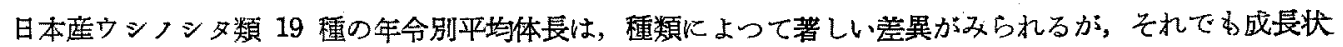

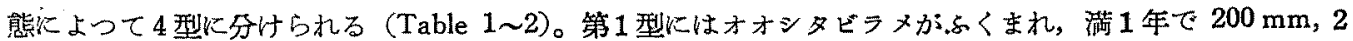
年て $300 \mathrm{~mm}, 3$ 年で $360 \mathrm{~mm} ， 4$ 年で $400 \mathrm{~mm}$ 内外㑢する。第2型にはクロウシノシタ，イヌノシタ,

Table 1. Standard length of each age computed from scales, estimated extremity body length, and the longest body length in samples of Japanese dextral soles

\begin{tabular}{|c|c|c|c|c|c|c|c|}
\hline \multirow{2}{*}{ Species } & \multirow{2}{*}{ Form } & \multicolumn{4}{|c|}{$\begin{array}{l}\text { Standard length in each } \\
\text { age (mm) }\end{array}$} & \multirow{2}{*}{$\begin{array}{l}\text { Extremity } \\
\text { body length } \\
\text { (mm) }\end{array}$} & \multirow{2}{*}{$\begin{array}{l}\text { Longest } \\
\text { body length } \\
\text { (mm) }\end{array}$} \\
\hline & & 1 & 2 & 3 & 4 & & \\
\hline $\begin{array}{l}\text { Pardachirus pavoninus } \\
シ ナ シ ウ シ ゙ シ タ\end{array}$ & Cosmopolitan & 100.0 & 148.0 & - & - & - & - \\
\hline 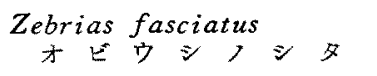 & Chinese & 82.0 & 135.3 & 176.5 & 196.0 & 290.0 & 217 \\
\hline 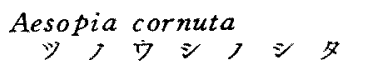 & Cosmopolitan & 90.0 & 140.0 & - & - & - & - \\
\hline $\begin{array}{l}\text { Zebrias zebra } \\
シ マ \nabla \\
シ\end{array}$ & Cosmopolitan & 67.5 & 103.8 & 125.6 & 155.5 & 210.0 & 187 \\
\hline 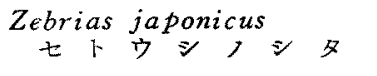 & Japanese & 65.5 & 96.2 & 118.4 & - & 173.0 & 143 \\
\hline 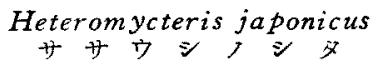 & Chinese & 60.9 & 81.0 & 92.0 & - & 108.0 & 128 \\
\hline $\begin{array}{l}\text { Aseraggodes kaianus } \\
\text { モシウウ }\end{array}$ & Tropical & 48.0 & 90.0 & 一 & - & - & - \\
\hline $\begin{array}{l}\text { A. kobensis } \\
\text { トビササウシノシタ }\end{array}$ & Japanese & 48.6 & 64.0 & 78.3 & - & 116.0 & 101 \\
\hline
\end{tabular}

Table 2. Standard length of each age computed from scales, estimated extremity body length, and the longest body length in samples of Japanese sinistral soles.

\begin{tabular}{|c|c|c|c|c|c|c|c|}
\hline \multirow{2}{*}{ Species } & \multirow{2}{*}{ Form } & \multicolumn{4}{|c|}{$\begin{array}{l}\text { Standard length in each } \\
\text { age }(\mathrm{mm})\end{array}$} & \multirow{2}{*}{$\begin{array}{l}\text { Extremity } \\
\text { body length } \\
\text { (mm) }\end{array}$} & \multirow{2}{*}{$\begin{array}{l}\text { Longest } \\
\text { body length } \\
(\mathrm{mm})\end{array}$} \\
\hline & & 1 & 2 & 3 & 4 & & \\
\hline $\begin{array}{l}\text { Arelia bilineata } \\
オ オ シ タ ゙\end{array}$ & Cosmopolitan & 203.2 & 303.0 & 363.0 & 397.0 & 440.0 & 431 \\
\hline 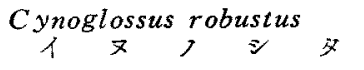 & Chinese & 136.2 & 221.0 & 261.7 & 311.3 & 400.0 & 393 \\
\hline 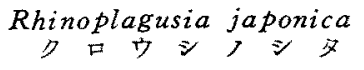 & Chinese & 122.0 & 203.2 & 272.0 & - & 420.0 & 334 \\
\hline 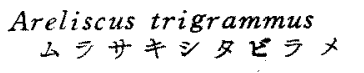 & Chinese & 123.0 & 205.0 & 258.8 & - & 400.0 & 327 \\
\hline $\begin{array}{l}\text { Paraplagusia blocki } \\
\text { ナショウウジシ }\end{array}$ & Cosmopolitan & 104.0 & 160.0 & - & - & - & - \\
\hline 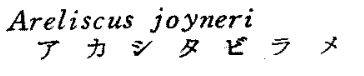 & Chinese & 98.5 & 142.5 & 166.2 & 210.3 & 325,0 & 245 \\
\hline 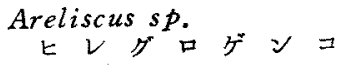 & - & 93.5 & 135.8 & 172.5 & 200.3 & 325.0 & 215 \\
\hline 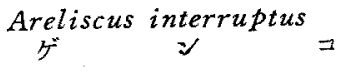 & Chinese & 71.5 & 104.0 & 135.2 & 154.3 & 245.0 & 172 \\
\hline $\begin{array}{l}\text { Symphurus strictus } \\
ヒ モ ウ シ ゙ ~\end{array}$ & Tropical & 72.0 & 100.4 & 110.1 & - & 113.0 & 131 \\
\hline 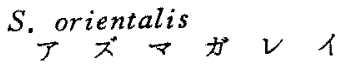 & Chinese & 60.6 & 86.5 & - & 一 & - & - \\
\hline 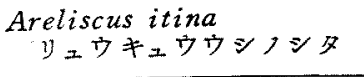 & Japanese & 50.0 & 71.2 & 87.2 & 102.9 & 150.0 & 143 \\
\hline
\end{tabular}


ムタサキシタビラメの3 䡒がふくまれ，1年で $130 \mathrm{~mm}, 2$ 年で $210 \mathrm{~mm}, 3$ 年て $260 \mathrm{~mm}, 4$ 年て 300

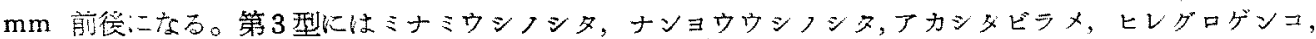
オビウシノシタ攻びッフウシノシタなどが属し，1年て $100 \mathrm{~mm}, 2$ 年を $140 \mathrm{~mm}, 3$ 年で $180 \mathrm{~mm}, 4$ 年 て $200 \mathrm{~mm}$ 前後に这する。第 4 型は矮小形のウジシ タ類てらのて、シマウシノジ,ゲシコ, ヒトウシノ シタ，上キウシノシタ，毛ウリシノシタ，てズマガ レイ、ササウシノシタ、リニウキュウジシタ，トビ サササシフシタなどがらくまれる。これでる分るよう に、ワシノシタ亜科人心く立れる㮔類の成長的分化は 著して4型の何れにも属するが，アボ、がレイ亜科 は矮形て，第 4 型にのみ属寸る。ササウシノジ科の 魚類は一般心小形て古つで，大部分のものは第4 型に 属して、る。ヒしてこの科内では，シャウシノシタ亚 科のものがトビサ甘市シンシタ改びササウシノシタ
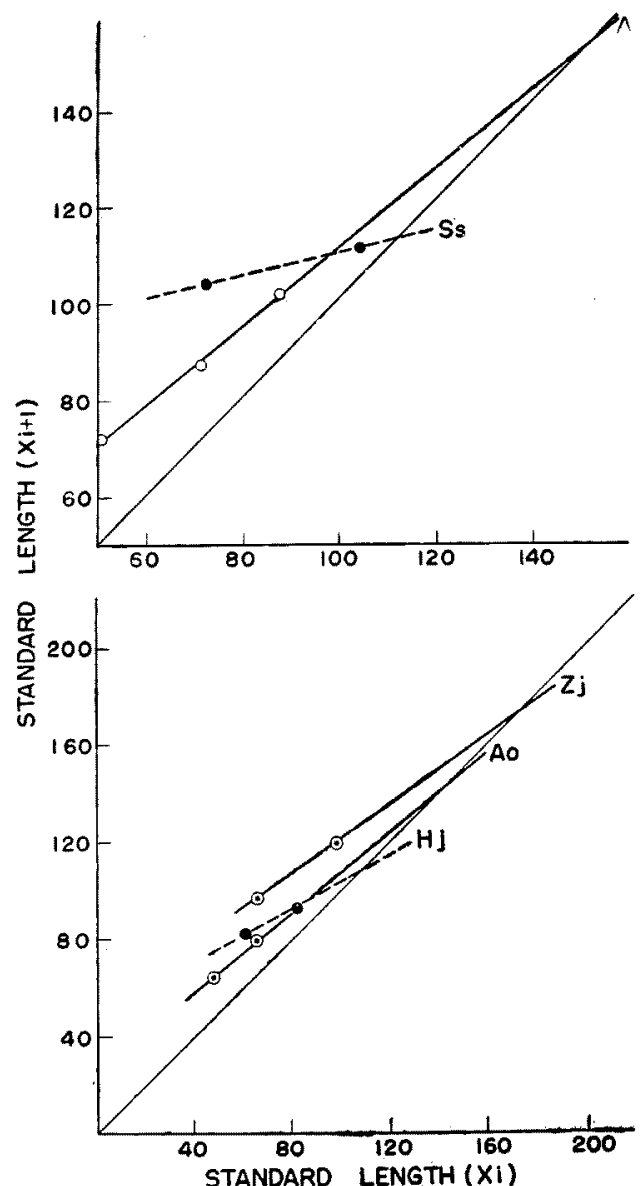

Fig. 1. Extremity body length estimated by the difference diagram in Japanese soles

A : Areliscus itina. Ao: Aseraggodes kobensis. $\mathrm{Hj}$ : Heteromycteris japonicus. Ss : Symphurus strictus. $\mathrm{Zj}_{\mathrm{j}}$ : Zebrias japonicus.
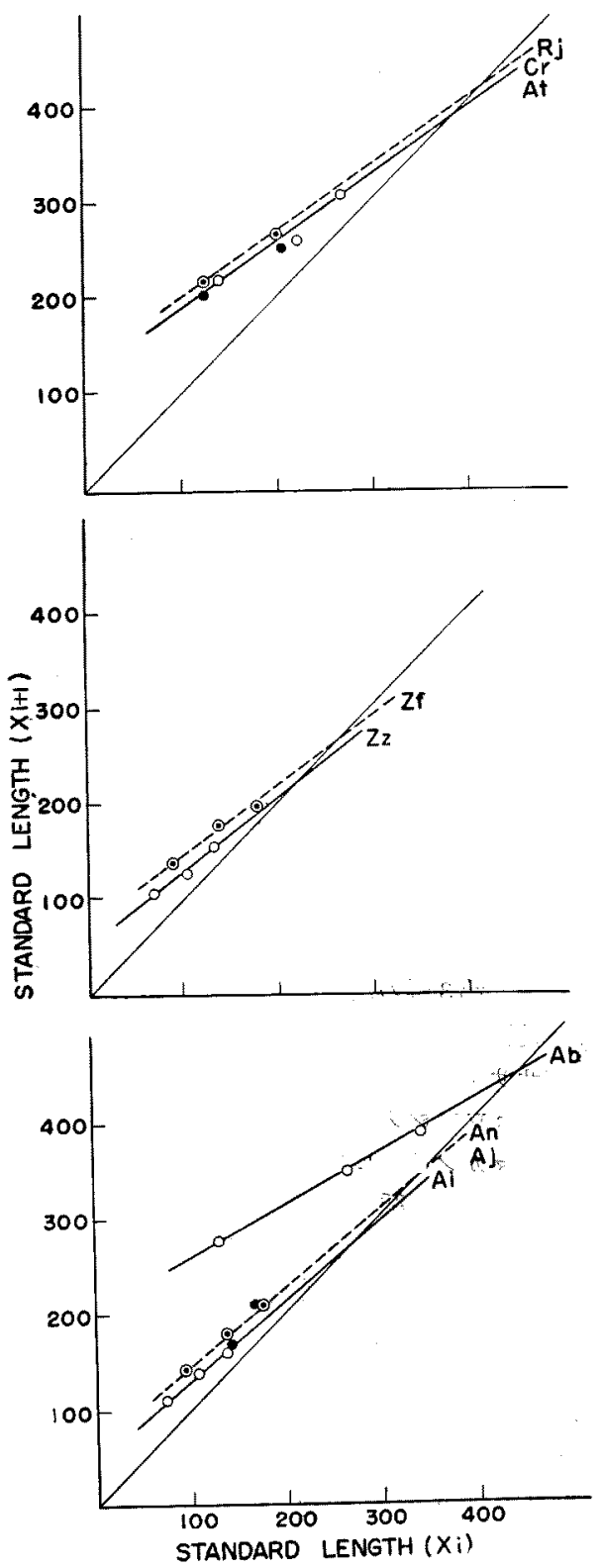

Fig. 2. Extremity body length estimated by the difference diagram in Japanese soles

$\mathrm{Ab}$ : Areliscus bilineata. $\mathrm{Ai}$ : Areliscus interruptus. Aj: Areliscus joyneri. An : Areliscus sp. At : Areliscus trigrammus. $\mathrm{Cr}$ : Cynoglossus robustus. $\mathrm{Rj}$ : Rhinoplagusia japonica. Zf : Zebrias fasciatus. $\mathrm{Zz}$ : Zebrias zebra. 
亜科のもの上り一般に大きい。

ウシノシタ亜科に属する種類の成長状態多様性をしめしたか，それでも第 4 型に属するるのは本土系ま

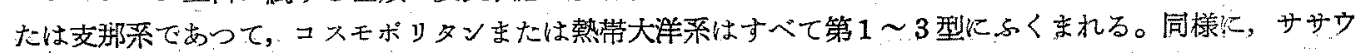
シノシタ科中第 3 型に入るのは熱带大洋系またはコスモポリタン系でつて，その他の系統のるのは第 4 型 に属する。

次に，成長状態から各魚種が到達する極限体長を定差図によつて推定することにする。体長が成長法則に

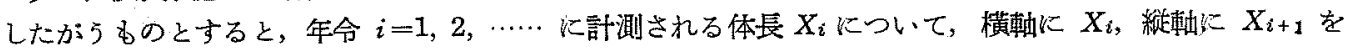
とると，これらの点は一つの直線上に並ぶ。その直線と横軸炕原点で 45 度の傾きを持つ直線との交点の座 標によつて体長の植限の大きさを推定することができる。日本産ウシノシタ類 14 種について極限体長を求 めると, Table 1,2, Fig. 1,2 の上うになる。これらの極限の体長によつて 14 種は次の 3 群に分けられ る。第1群はオオシタビラタ, イヌノシタ，クロウシフシタムラサキシタビラタなどによつて代表される bので，極限体長は $400 \mathrm{~mm}$ 前後達する。第2 群はフカシタビシメ，ヒレグロゲンコ改びオビウシノシ タなどで代䇈され，体長は $300 \mathrm{~mm}$ 前後になる。第 3 群にはササウシノシタ，ヒモウシノシタ，トビササ ウシノシタ,リュウキニウウシノシタ,セトウシフシタ,シマウシノシタ，ゲンコなどがふくをれ，極限体長 は $245 \mathrm{~mm}$ 以下である。著者が調查した標本中の最大体長は Table 1,2 にかかげたが，こ和らと比較す ると極限体長はまず妥当なようである。ただ，クロウシノシタムムラサキシタビラメ，アカシタビシメ， ヒ レグロゲンコ，ゲンコなどの極限体長は最大体長よりも著しく大きい。

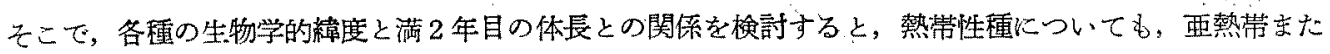
は温带性種についても成長の異る群があり，文れらが各か対応していることが判明する(Fig. 3)。つまり， オオシタビラメとイヌノシタ，ムシサキシタビラメ，クロウシノシタとが(第1群)，ナンヨウウシフシタ， ミナミウシノシタ，ッフウシノシタとアカシタビラメ，オビウシノシタとが(第2 群)，モヨウウシノシタ， ヒモウシノシタ, シマウシノシタとがンコ, ササウシノシタ, リュキュウウシノシタ, セトウシノシタ, ト ビササウシノシタ，フズマがレイとが(第3群)それぞれ対応している。これらの各対応は極限体長からみて 同じ群に属するか，または同一群㶤属すると思わ れるあのであり，各対応を通じて熱带系のものが その他のもの上りむ多少とも大きい、傾向がみとめ られる。第 3 群のなかでも，同一属にふくまれる 熱带性種と本土系に属する種類とを検討すると， トビササウシノシタフズマ種 (トビササウシノシ タとモシウウシノシタ), 属の 2 がレイ属の 2 種 (ナス゚ーがレイとヒモウシノシタ）欧びシマノウ シノシタ属の2 種 (シマウシノシタとセトウシノ シタ）では常に熱帯種の成長がよい。

次に, 同一属内の成長度合と形態とくに体節的 棈造とがどのような関係にあるかを調べる。体節 的構造としては垂直䱛軟条数, 资椎骨数, 側線鲜 数等があげられるが，これらのうち资椎骨数が最 も安定している。しふし本邦産のウシノシタ類で は繁鰖軟条数々脊椎骨数との間以は密接な関保が あり，前者の後者注対する割合は，ササウシノシ 科で 1.3 1.5, ウシノシ夕科で 1.6〜1.7 で

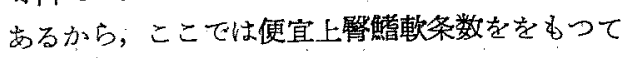
体節的構造を代表さすことにする。トビササウシ フシタ属, シマウシクシタ属, アカシタビラメ属 及ぶアズマガレイ属などについて，2 年魚の体長

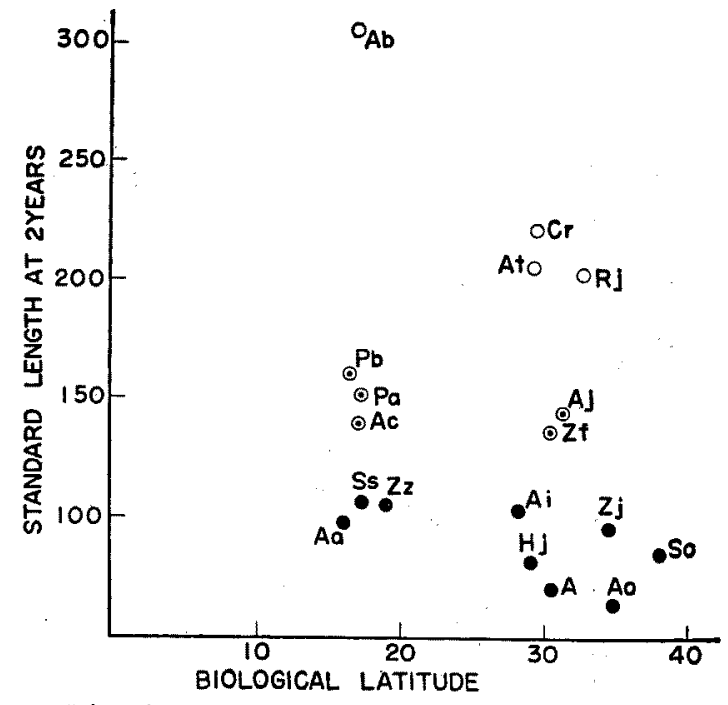

Fig. 3. Relation between biological latitude (average value of their habitable limits expressed by the geographical latitude) and the standard length at 2 years in Japanese soles

Aa : Aseraggodes kaianus. Ac : Aesopia cornuta. Pa : Pardachirus pavoninus. " $\mathrm{Pb}$ : Paraplagusia blocki. So : Symphurus orientalis.

O 1 st group. $O 2$ nd group.
3 rd group. 
と鯧条数との関係をしらべると Fig.4 のよ うになる。トビササウシノシタ属の 2 種間で は, 鱪条数汇差がみられないが体長にはかな りの差異がある。シマウシノシタ属ではオビ ウシノシタ, シマウシノシタ, セトウシノシ タの順に体長か減少するが，臂鰙軟条数はオ ビウシノシタだけがとくに多い。ナカシタビ ラメ属では全体として案数が增すと体長も大 きくなる傾向がある。しかし，ゲンコはつカ シタビラメ，ヒレグロゲンコなどと条数が注 涪等しいが，体長はそれらよりい小さいて ズマガレイ゚属の 2 種では条数と体長の增減と が相ともなら。

これらのことから，初期の成長と体節的構 造との間にはかなり密接な関係にあることが 分る。しかし，この両者は常に比例的な関保 にあるわけでなく，ある一定の觰条数をるつ

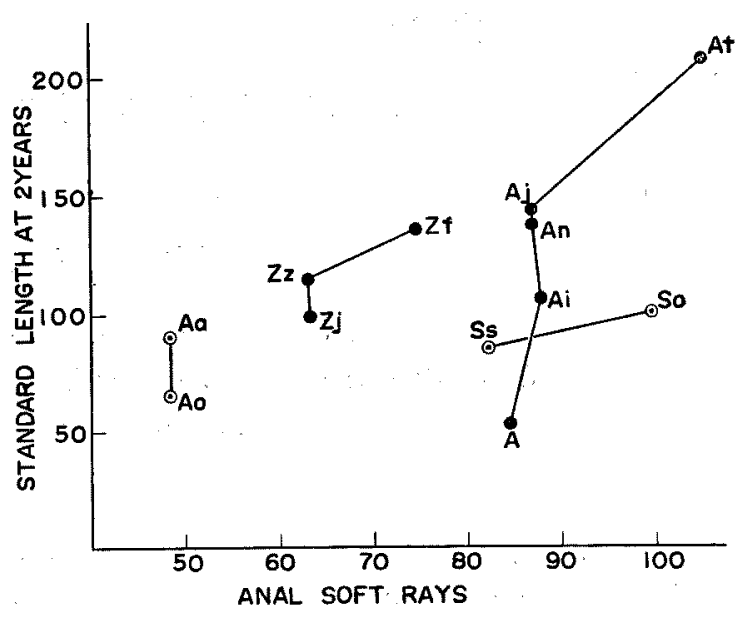

Fig. 4. Relationship between anal soft rays and standard length at 2 years in some Japanese soles 種類間でも成長的な分化がみとめられるが，それにはある程度の限界があるようである。

\section{む す び}

日本近海産ウシノシタ魚類の成長をいろいろの面から解析した。その結果まず同亜科内の種類間には，そ れらの成長状態をある種の限界があることが判明した。また同属の種類間では熱带性種が本土系の種類より る大型になる傾向がある。一方，成長状態は体節的構造とも密接な関係に嵓り，同属内ではこの構造の多い

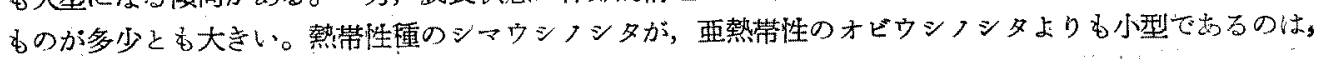
前者の体節的構造が後者のそ札よりる少いことと関連があると思われる。

本土系のリュウキュウウシノシタ，セトウシノシタ，トどササウシノシタ，アズマガレイなどは，同属内 の熱带系，支那系比整して体節的構造も少く何れも矮小型である。これに対して，イヌノシタ，オビウシ ノシタ、ムラサキシタビラメ，アカシタビシメ仪びクロウシノシタなどの支那系は大型てあつて日本蓙ウシ ノシタ資源中最も重要なものである。 